Un hombre muere en mí siempre que un hombre muere en cualquier lugar, asesinado por el miedo y la prisa de otro hombre...

O es tan puro que se vuelve conciencia estética:

\author{
Porque todo poema \\ es un pacto de paz entre los hombres...
}

La vuelta de Jaime Torres Bodet a su patria -quiero decir a la poesía- es de valor simbólico. En su peregrinaje por tierras extrañas - Ministerio de Educación, embajadas, Unesco- invistió de alto prestigio la faena burocrática y fué en más de un sentido "un extraño". Ahora, reintegrado, en lustral actitud, vuelve a arder en él la antigua llama del hondo lirismo.

\title{
A. Torres-RToseco.
}

\section{Luis Amílcar Raudales, Baturrillo bistórico. - Tegucigalpa, 1954, 104 pp.}

Corre la anécdota el riesgo de haber sido inventada tendenciosamente. No pocos la consideran como dato histórico y son más los que la cultivan y la adornan, para estimular la avidez de quienes se solazan conociendo intimidades, a veces deletéreas. Los ejemplos son numerosos, y

muchos que escriben la historia los intercalan como si fueran testimonios irrefutables. Desde el libro del cubano Emilio Sotolongo hasta el reciente Anecdotario nacional del costarricense Carlos Fernández Mora, hay una bibliografia extensa.

Todo hombre sobresaliente ha dado vida a una anécdota. El folklorista las teúne, el periodista las repite, el pueblo también las crea y perpetúa, así como ha creado personajes de la talla del general Santibáñez en México, el general Reyes en Guatemala y Juan Lama y el general Canevaro en el Perú. En este baturrillo figuran algunos datos que se han repetido tradicionalmente $y$ que deben ser examinados cuando se revaloren las investigaciones folklóricas en Honduras. 
El peligro de repetir una anécdota se halla en creerla oriunda de la tierra en que se ha contado o adobado, o en la admiración o el desdén hacia un personaje que le ha dado carta de legitimidad. Así, por ejemplo, hay una atribuída a un virrey de Nueva Esparia, el Segundo Conde de Revillagigedo - aquella de la viuda que pretendía rescatar sus joyas dadas en prenda - que aparece relatada en el Museo Mexicano de mediados del siglo $\mathrm{xIx}$ y que los promulgadores de las grandezas del dictador Justo Rufino Barrios no tuvieron mínimo empacho para convertirla en flor de su guirnalda. $\mathrm{Ha}$ ocurrido en otras ocasiones una transculturización de la anécdota: la inventada por Ricardo Palma sobre fray Gómez, el del alacrán de piedras preciosas, y que ha repetido otro escritor de otro país americano, sin superar la gracia encantadora con que telata el peruano, quien fué gran inventor con patente de anécdotas coloniales; quiere decir que lo que salvó a éstas fué el ingenio del insigne escritor para arrancarlas del papel viejo y reanimarlas con su mágico estilo.

Sin embargo, los anecdotarios como el de Fernández Mora, cuya aparición coincide con el del profesor Raudales, tienen innegable mérito: el de atraer la atención de los lectores hacia el mundo de la historia, que siempre es nuevo mundo. $\mathrm{Y}$ este es motivo para felicitarles.

Ha podido el profesor Raudales salvar del olvido algunos episodios y acaeceres de la historia hondureña, así como versos anónimos del tiempo pasado y sucedidos en que son protagonistas varios funcionarios públicos, educadores o simples personajes de vida momentánea.

RubÉN Darío (hijo), La amargura de la Patagonia.-Buenos Aires, Editorial Nova, 1950, 315 pp.

Como si fuera invitación al advenimiento de un alba nueva, que ilumine la felicidad de los argentinos que viven en Patagonia; sobre todo, los que en ella trabajan la tierra, apareció este libro como un toque de alarma en pro de la reivindicación económica de una tierra que, a la distancia, ha ofrecido un falso espejismo a los geógrafos y a los emigrantes optimistas.

Darío (hijo) ha residido algún tiempo en la Argentina, y no en vano. Leyendo esta novela se puede llegar a la conclusión de que ha recogido informaciones de primera mano en el país austral, conversando 